\title{
Location and timing of the deposition of egg strands by perch (Perca fluviatilis L.): the roles of lake hydrology, spawning substrate and female size
}

\author{
M. Čech ${ }^{(1)}$, J. Peterka ${ }^{(1)}$, M. Říha ${ }^{(1)}$, M. Muška ${ }^{(1)}, J . H_{e j z l a r}^{(1)}$, J. Kubečka ${ }^{(1)}$ \\ Received May 24, 2011 \\ Revised June 22, 2011 \\ Accepted July 25, 2011
}

\section{ABSTRACT}

Key-words:

SCUBA diving, Aquatic vegetation, Common stonewort, Chara vulgaris, Common reed Phragmites communis, Lake management

The reproduction biology of perch Perca fluviatilis was studied in relation to lake hydrology, spawning substrate and female size using SCUBA divers during late April and mid-May 2009 in Chabařovice Lake, Czech Republic. An extreme displacement of water mass, induced by a long-lasting strong wind, caused the abundance of egg strands to differ significantly between individual parts of the lake. On average, $91 \%$ of perch spawning activity occurred at depths greater than $3 \mathrm{~m}$. The mean concentration of dissolved organic carbon $(D O C)$ indicated that the lake belongs to the category where $D O C$ influencing the penetration of ultraviolet radiation, is not responsible for the deep deposition of egg strands by perch. Most probably, the avoidance of shallow depths $(<3 \mathrm{~m})$ results from strong wind/waves coming from any direction. Larger perch females started to spawn earlier than their smaller conspecifics and they used shallower depths for depositing their egg strands. As a spawning substrate, perch strongly selected dead submerged vegetation, such as common reed Phragmites communis and worm weed Artemisia sp. These substrates, however, reveal signs of progressive degradation and seem likely to disappear from the lake within several years.

RÉSUMÉ

Lieu et date de la ponte des rubans d'œufs par la perche (Perca fluviatilis L.) : les rôles de l'hydrologie lacustre du substrat de ponte et de la taille des femelles

Mots-clés : plongée sous-marine, végétation aquatique, Chara vulgaris, armoise, roseau commun
La biologie de la reproduction des perches Perca fluviatilis a été étudiée en relation avec l'hydrologie lacustre, le substrat de ponte et la taille des femelles par des plongeurs de la fin avril à la mi-mai 2009 dans le lac Chabařovice, République Tchèque. Un déplacement extrême de la masse d'eau, induit par un vent fort de longue durée, a provoqué une abondance des rubans d'œufs différant considérablement entre les différentes parties du lac. En moyenne, $91 \%$ de l'activité de frai des perches est survenue à une profondeur supérieure à $3 \mathrm{~m}$. La concentration moyenne en carbone organique dissous $(D O C)$ indiquant que le lac appartient à la catégorie où le $D O C$ influence la pénétration du rayonnement ultraviolet, n'est pas responsable du dépôt profond de rubans d'œufs par la perche. Très probablement, l'évitement des faibles profondeurs $(<3 \mathrm{~m})$ résulte du vent fort et/ou des vagues venant de n'importe quelle direction. Les plus grandes perches femelles

(1) Biology Centre, Academy of Sciences of the Czech Republic, Institute of Hydrobiology, Na Sádkách 7, 370 05 České Budějovice, Czech Republic, carcharhinusleucas@yahoo.com 
ont commencé à frayer plus tôt que leurs congénères plus petites et elles ont utilisé des profondeurs plus faibles pour le dépôt de leurs rubans d'œufs. Comme substrat de frai, la perche a fortement sélectionné la végétation morte submergée telle que le roseau commun Phragmites communis et l'armoise. Ces substrats, cependant, montrent des signes de dégradation progressive et semblent susceptibles de disparaître du lac dans quelques années.

\section{INTRODUCTION}

The location and timing of perch [Perca fluviatilis L. in Eurasia; $P$. flavescens (Mitchill) in North America] spawning activity is influenced by many biotic and abiotic factors, among which temperature and spawning substrate seem to be the most important (e.g. Treasurer, 1983; Rask et al., 1990; Gillet et al., 1995; Gillet and Dubois, 1995; Sandström et al., 1997; Huff et al., 2004; Gillet and Dubois, 2007; Čech et al., 2009). Frequently lake hydrology and, especially, prevailing wind and from that resulting waves, also contributed significantly to the place and depth of egg strand depositions as well as to the length of the spawning period (Jones, 1982; Newsome and Aalto, 1987; Probst et al., 2009). It has also been suggested from large pre-alpine lakes (Lake Geneva, Lake Constance) that larger female perch have a tendency to spawn later than small ones and that they use deeper spawning places (Gillet et al., 1995; Gillet and Dubois, 2007; Probst et al., 2009). Completely opposite results have, however, been published from Klíčava Reservoir, Czech Republic (Holčík, 1969; female size only) and from an inundated quarry pit, La Gombe, Belgium (Dalimier et al., 1982). More recently, Williamson et al. (1997) and Huff et al. (2004) have shown that the concentration of dissolved organic carbon $(D O C)$ plays a crucial role in the depth distribution of egg strands. In low-DOC lakes (DOC $\sim 1.1 \mathrm{mg} \cdot \mathrm{L}^{-1}$ ) where damaging ultraviolet radiation (UVR) penetrates to deeper layers of the water column, perch, in an effort to protect their eggs, are forced to spawn in much greater depths compared to higher-DOC lakes (DOC $\geqslant 4.7 \mathrm{mg} \cdot \mathrm{L}^{-1}$; Huff et al., 2004).

The present study focused on the location and timing of the deposition of egg strands by perch in the newly created Chabařovice Lake. In this lake, Čech et al. $(2009,2010)$ have previously reported that $92 \%$ (year 2007) and $88 \%$ (2008) of egg strands were deposited at depths greater than $3 \mathrm{~m}$ which closely resembles the situation in the low-DOC Lake Giles, Pennsylvania, described by Huff et al. (2004; 92\% of egg strands were deposited at depths greater than $3 \mathrm{~m}$ ). In Chabařovice Lake, the concentration of $D O C$ has never been analyzed. Moreover, it is believed that other factors such as the presence of an appropriate spawning substrate, temperature and wind (coming from all directions due to deforestation of the surrounding landscape) are responsible for such deep deposition of egg strands (in extreme up to more than 20 m; Čech et al., 2009, 2010).

The main questions of the present study were: (1) Is the location of perch egg strands deposition affected by the lake's hydrology, especially by a long-lasting strong wind in one direction causing water mass displacement? (2) Is the deep deposition of egg strands reported for Chabařovice Lake by Čech et al. $(2009,2010)$ a result of low DOC concentration in the lake or is it more likely a result of cumulative effect of e.g. wind/waves, temperature and the presence or absence of appropriate spawning substrates? (3) Does the size of egg strands differ during the spawning season or with depth of spawning? (4) Does the size of egg strands differ according to the spawning substrate used (dead or living submerged vegetation at least)? This study is part of a long-term project focusing on succession processes in a newly created opencast mine lake (see also Čech et al., 2009, 2010).

\section{MATERIALS AND METHODS}

\section{$>$ STUDY AREA}

The study was carried out in the oligo- to mesotrophic Chabařovice Lake, Czech Republic (80 km north-west of Prague), which has an area of c. 200 ha, volume of $18 \times 10^{6} \mathrm{~m}^{3}$ and 
(a)

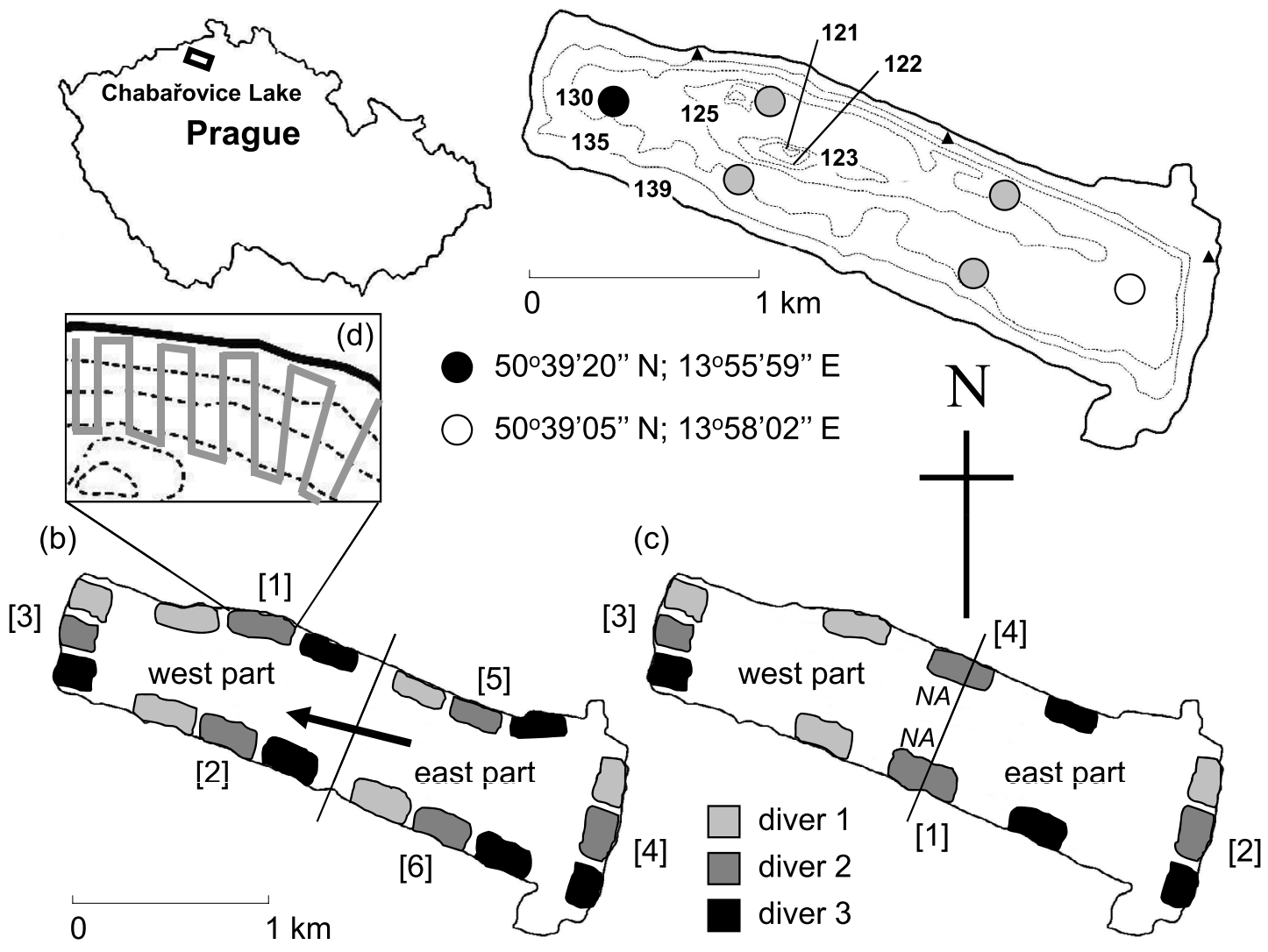

Figure 1

A map of Chabařovice Lake and its location in the Czech Republic. (a) Contour map of the lake. Numbers indicate bottom altitude in meters above sea level. Dots (black, grey, white) indicate places from which water for measurement of dissolved organic carbon was taken and where temperature as well as dissolved oxygen was measured in the whole water column on 28 April and 19 May 2009 (in May the DOC data were provided by the Elbe River Authority). At those points Secchi disc depth was also measured. Longitude and latitude of the black and white dots is given (data used in Figure 3). Black triangles indicate locations where surface water temperature was measured daily from 15 March 2009. (b, c) A schematic distribution of the individual diving localities where three divers simultaneously monitored egg strands and spawning substrates of perch. Numbers in brackets show the order of sampling. (b) 27-30 April 2009. The black arrow shows the direction of the long-lasting strong wind prior to and during the sampling period. (c) 18-20 May 2009. NA, these localities were not included into the analysis of the lake hydrology effect on the location of perch egg strands deposition. (d) An example of the systematic parallel transect sampling (diver No. 2; 10 transects) from $0 \mathrm{~m}$ towards the $12 \mathrm{~m}$ depth. The short turning trajectories at a depth of 0 and $12 \mathrm{~m}$ were not sampled.

maximum depth of $22 \mathrm{~m}$ (Figure 1a). Chabařovice Lake is a newly created, opencast mine lake where aquatic restoration started in 2001 (Čech et al., 2009, 2010). The water level did not fluctuate during the study period. This water body has no obvious limitation to perch spawning activity in terms of depth and spawning substrates, which are numerous (e.g. dead trees, dislodged branches, bushes, beds of dead common reed Phragmites communis and worm weed Artemisia sp., Eurasian water milfoil Myriophyllum spicatum and common stonewort Chara vulgaris) and some of which are present to the deepest part of the lake (Čech et al., $2009,2010)$. However, especially the beds of dead common reed and worm weed, the most important substrates for perch spawning, reveal signs of progressive degradation and this substrate seems likely to disappear from the lake within several years (Čech et al., 2009, 2010). 
Despite the extensive stocking programme focusing on larger individuals of pike Esox lucius L., zander Sander lucioperca (L.) and wels catfish Silurus glanis L. (years 2005-2007; for biomanipulation purposes), perch is still the most abundant predatory fish in the lake, and a key species, significantly affecting the whole lake ichthyofauna (Peterka et al., 2009; Peterka and Čech, unpubl. data).

\section{$>$ SAMPLING}

Three SCUBA divers simultaneously monitored perch spawning activity in the 0-12 m depth layer (systematic parallel transect sampling) during 27-30 April and 18-20 May 2009. At individual localities, the divers were landed from the boat at a distance of at least $400 \mathrm{~m}$ (north and south banks) or $200 \mathrm{~m}$ (west and east banks) from each other according to GARMIN GPSmap 60CS $\times$ (Figure 1b and 1c). Each diver swam from a very shallow littoral zone (depth $0 \mathrm{~m}$ ) towards the depth of $12 \mathrm{~m}$ (transect 1), sampling the space $3 \mathrm{~m}$ to each side of him, then turned $90^{\circ}$, performed ten standard fin strokes (c. $15 \mathrm{~m}$ distance - not sampled), turned another $90^{\circ}$ and swam back from $12 \mathrm{~m}$ deep towards the $0 \mathrm{~m}$ depth (transect 2; Figure 1d). In total, 168 transects were sampled during 27-30 April (18 day dives, $20 \mathrm{~h}$ underwater) and 120 transects during 18-20 May 2009 (12 day dives, $14 \mathrm{~h}$ underwater). In contrast to the previous studies of Cech et al. (2009, 2010; sampling in various depth layers parallel to the shore) from the years 2007 and 2008, in 2009 a different sampling scheme was used in order to monitor all the depth layers more equally. The depths $>12 \mathrm{~m}$, although comprising a spawning habitat for perch, especially at the end of the spawning period (cf. Ceech et al., 2009, 2010), were omitted from sampling because (i) depths $>12 \mathrm{~m}$ comprised almost $60 \%$ of the lake which would make the research even more demanding and because (ii) the proportion of greater depths in the lake is much less equal in comparison to shallower depths $(0-12 \mathrm{~m}$ in particular). Chabařovice is a trough-like lake with more or less uniform slopes but with a moon landscape with many craters of various and unpredictable depths (a result of coal mining) on the main bottom (Figure 1a). In this area (depths $>12 \mathrm{~m}$ ), perch egg strands are deposited on dead common reed, trees and branches, which distribution is, however, extremely scarce $(<1 \%$ of the ground coverage) and patchy (Čech, unpubl. data).

During both sampling surveys, the divers recorded the type of substrate on which individual egg strands were deposited, the depth of their deposition and the sizes of the egg strands (width; using a ruler). This information was noted under water on a plastic slate for each individual egg strand in each individual transect. The sizes of the spawning perch females were reconstructed from the width of individual egg strands using the equation of Dubois et al. (1996).

A detailed substrate survey was carried out at the same time as the monitoring of perch spawning activity. For the purpose of the present study, the categories of potential perch spawning substrate recorded were as follow: (i) flooded terrestrial vegetation, (ii) trees and branches, (iii) Eurasian water milfoil, (iv) common reed, (v) worm weed, (vi) common stonewort and vii) others. The large stands of curly pondweed Potamogeton crispus observed in the lake in 2007 (Čech et al. , 2009) were much less abundant in year 2008 ( $\ll 5 \%$ of the 2007 situation; Čech et al., 2010), and had completely vanished from the lake in 2009. The actual ground coverage occupied by individual spawning substrates, with a clear dominance of common stonewort, especially in the 3-11 m depth layers (fourfold increase in abundance compared to 2007 situation) is given in Figure 2.

Temperature and dissolved oxygen in the whole water column were measured using a calibrated YSI 556 MPS probe on 28 April and 19 May (midday). Surface water temperature was measured daily (morning) from 15 March at three separate locations around the lake shore (Figure 1a) in order to catch the beginning of the perch spawning period at $8-10^{\circ} \mathrm{C}$ (Kubečka, 1992). Water for DOC measurement was taken from the epilimnion, $30 \mathrm{~cm}$ below the water surface, at 6 places equally distributed around the lake (Figure 1a). This water was filtered in the field, cooled and transported to the laboratory. DOC was analyzed in the samples filtered through GF-5 filters with a TOC 5000A analyzer (Shimadzu, Japan). 


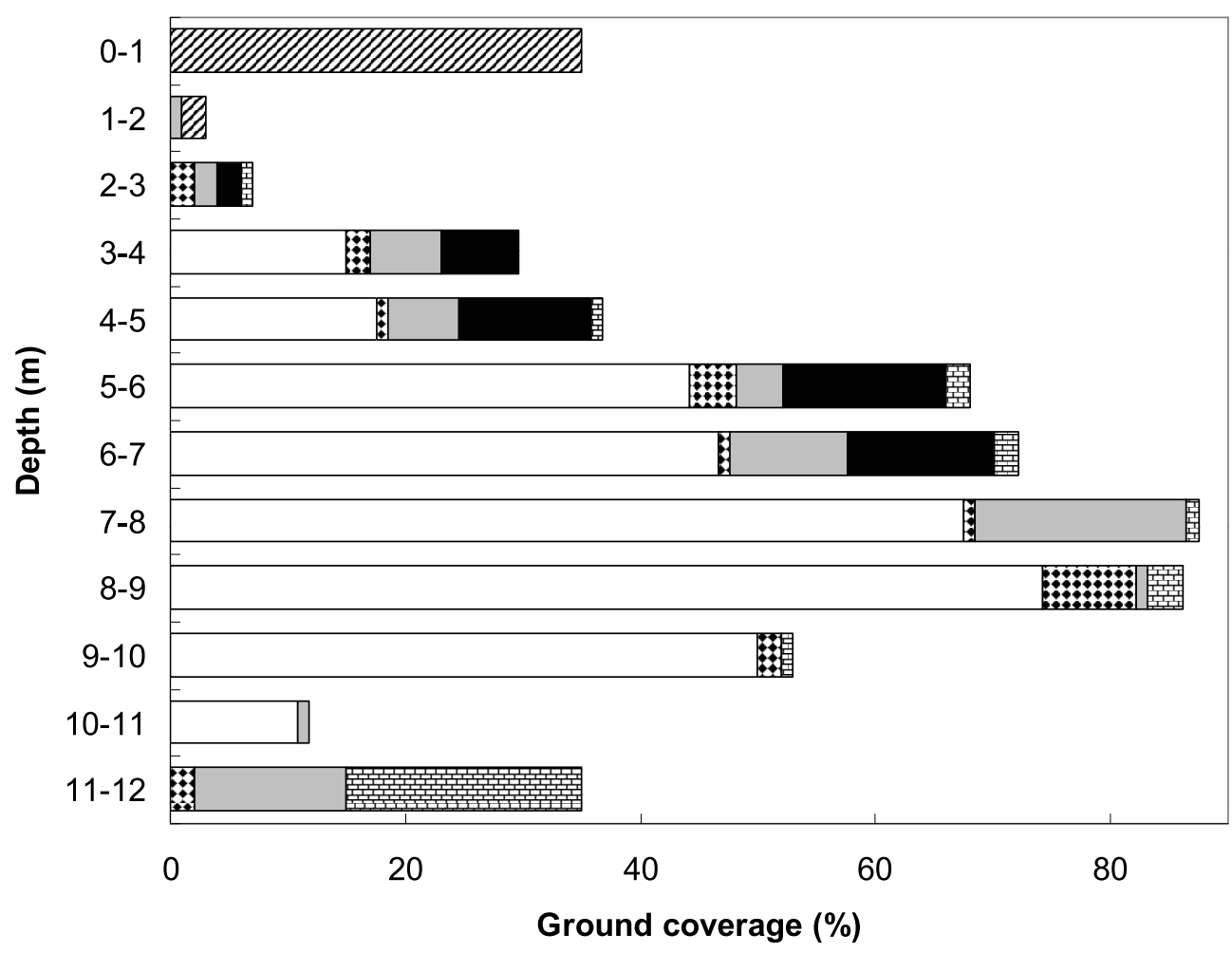
ש Flooded terrestrial vegetation (3.1\%)
国 Trees and branches $(3.1 \%)$
Eurasian water milfoil (3.9\%)
$\square \quad{ }^{\dagger}$ Common reed (5.6\%)
(3) Whorm weed $(2.1 \%)$

\section{Common stonewort $(27.2 \%)$}

Figure 2

Distribution of potential spawning substrates for perch in Chabařovice Lake in spring 2009 in 0-12 m depth layers. Mean ground coverage of individual spawning substrates for the whole vertical profile sampled is given in parentheses (total ground coverage composed of submerged vegetation in the 0 $12 \mathrm{~m}$ depth layers was $44.9 \%$; bare bottom, especially mud and boulders, covered the rest).

The data were tested using the Mann-Whitney U-test (lake hydrology effect on location of egg strands deposition), Kruskal-Wallis test (site and period related depth distribution of egg strands; size of egg strands in individual sampling periods), one-way ANOVA for unequal $n$ (size of egg strands according to the spawning substrate exploited), regression analysis (relationship between the size of egg strands and the depth of deposition) and $\chi^{2}$-test (spawning substrate preferences - dead vs. live submerged vegetation). The selection by perch females of appropriate spawning substrate was evaluated using the Ivlev index (Ivlev, 1961).

\section{$>$ RESULTS}

During and prior to the first sampling survey (27-30 April) a strong wind coming from the East (12-15 $\mathrm{m} \mathrm{s}^{-1}$; Czech Hydrometeorological Institute, unpubl. data) prevailed in the Chabařovice area. Large waves transported the warm, surface water to the west part of the lake (mean temperature in the upper $8 \mathrm{~m}$ of the water column $12.9^{\circ} \mathrm{C}$; Figure 3 ). Consequently, these water masses pushed the cold, deep water to the east part of the lake (mean temperature in the upper $8 \mathrm{~m}$ of the water column only $8.2{ }^{\circ} \mathrm{C}$; Figure 3 ). This temperature 
(a)

$$
\mathrm{T}\left({ }^{\circ} \mathrm{C}\right) \mathrm{O}_{2}\left(\mathrm{mg} \mathrm{l}^{-1}\right) \quad \text { (b) } \mathrm{T}\left({ }^{\circ} \mathrm{C}\right) \quad \mathrm{O}_{2}\left(\mathrm{mg} \mathrm{l}^{-1}\right)
$$
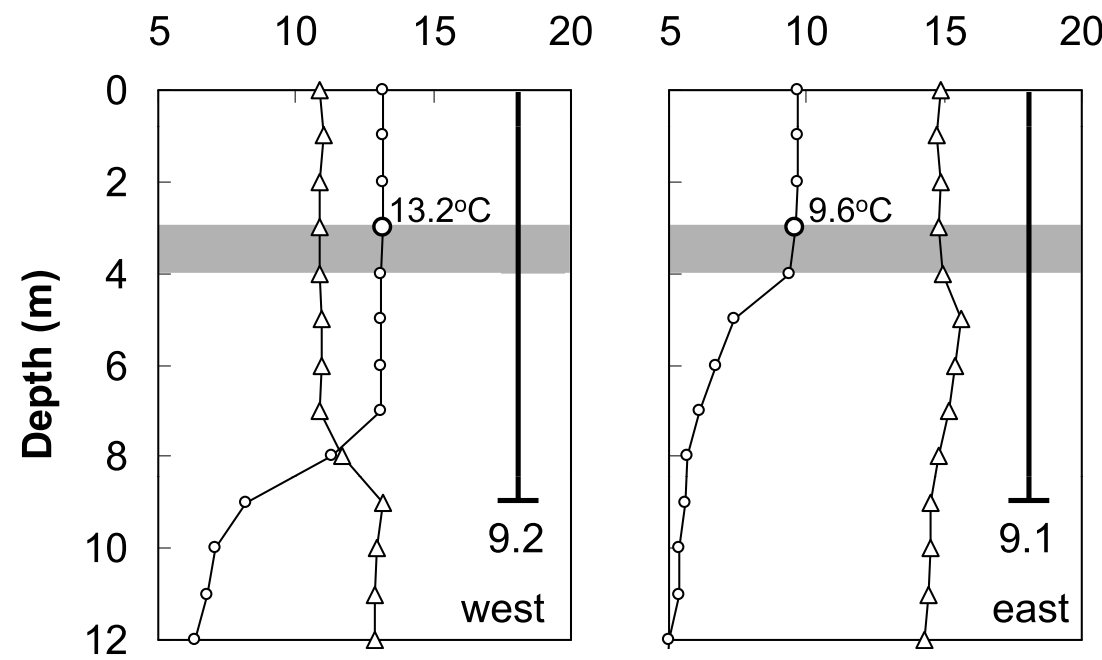

(c)

(d)
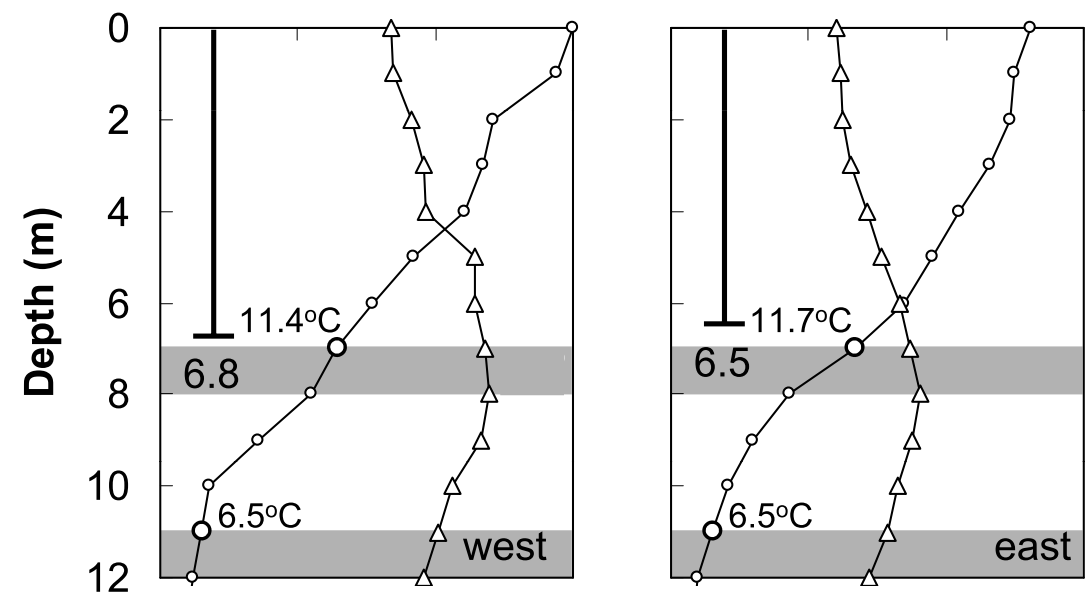

$$
-\triangle \mathrm{O}_{2}\left(\mathrm{mg} \mathrm{l}^{-1}\right)
$$

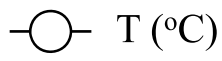

\section{Figure 3}

Comparison of the vertical profiles of temperature and dissolved oxygen measured at noon on (a, b) 28 April and (c, d) 19 May 2009 in Chabařvice Lake in the west and east parts of the lake (cf. Figure 1). The horizontal grey bars indicate the depth layers where most egg strands occurred during the first (27-30 April) and the second (18-20 May) sampling surveys (whole lake peak; cf. Figure 4). The vertical bars show the Secchi disk depths.

difference caused the abundance of egg strands of perch to differ significantly between the west and the east parts of the lake (Mann-Whitney $U$-test; $P<0.01$ ) being, on average, 0.56 egg strands $\cdot$ transect $^{-1}$ in the warmer west part and only 0.16 egg strands $\cdot$ transect $^{-1}$ in the colder east part of the lake. The mean depth of egg strands deposition, however, did not differ between the west and the east part of the lake (Kruskal-Wallis test; $P=0.42$ ) being $4.3 \mathrm{~m}$ and $4.2 \mathrm{~m}$, respectively.

During the second sampling survey (18-20 May), a long period of calm weather had caused stabilization of the water column in the whole lake. The temperature was similar in both parts of the lake (mean temperature in the upper $8 \mathrm{~m}$ of the water column $15.3^{\circ} \mathrm{C}$ in the west and $14.9^{\circ} \mathrm{C}$ in the east part of the lake; mean temperature in the upper $12 \mathrm{~m}$ of the water column 


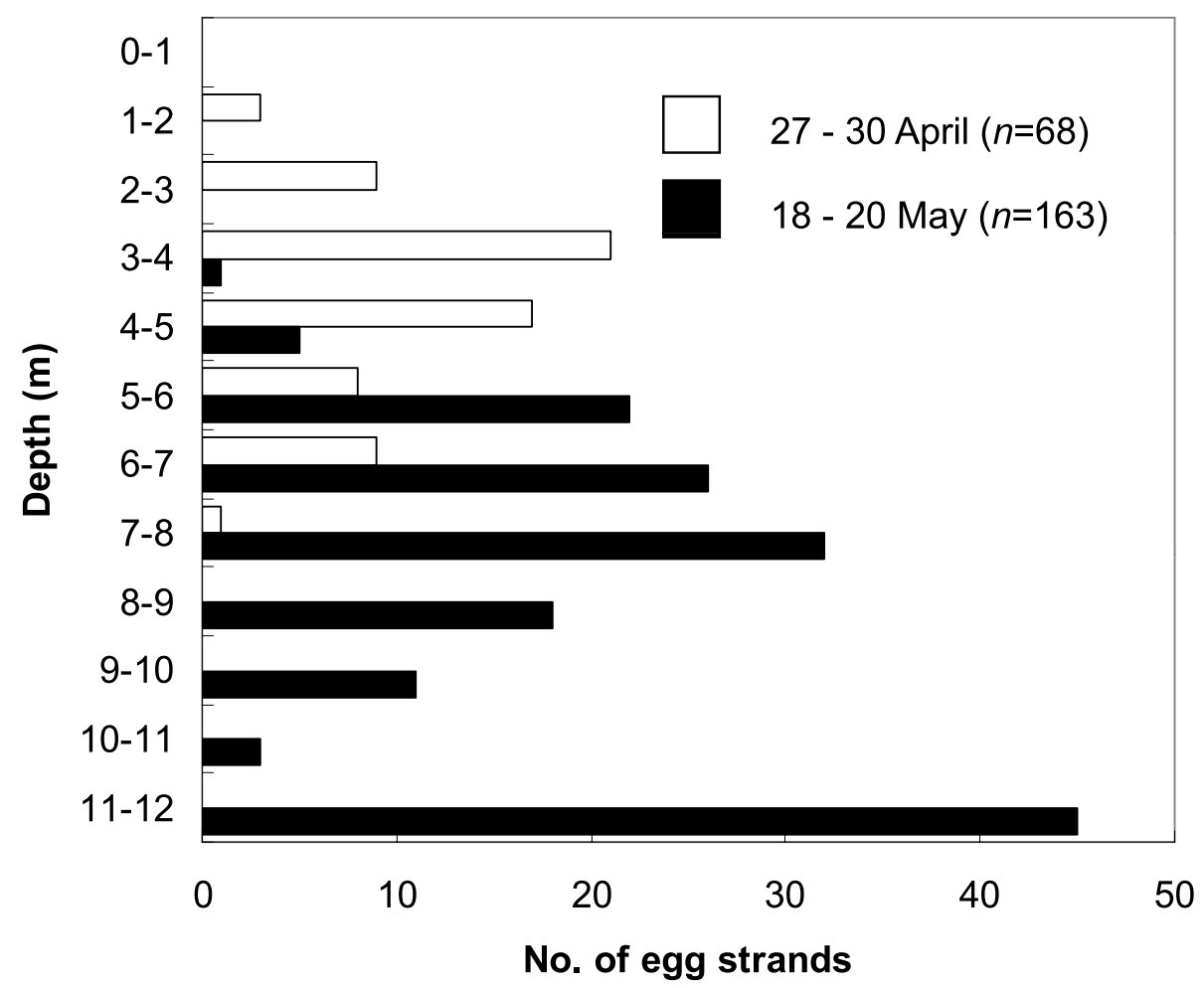

Figure 4

Depth distributions of egg strands of perch in Chabařovice Lake in spring 2009 during 27-30 April (mean depth $4.2 \mathrm{~m}$ ) and 18-20 May (mean depth 8.6 m). Note that only 0-12 m depth layers were sampled and that in Chabařovice Lake, according to previous results of Čech et al. (2009, 2010), up to 10\% of egg strands is usually spawned at depths $>12 \mathrm{~m}$. $\mathrm{n}$, total number of egg strands found during individual sampling surveys.

$12.8^{\circ} \mathrm{C}$ in the west and $12.4^{\circ} \mathrm{C}$ in the east part of the lake; Figure 3). This stabilization of the water column meant that there was no longer any significant difference in the abundance of egg strands between the two parts of the lake (on average 2.1 and 1.5 egg strands $\cdot$ transect $^{-1}$ in the west and east parts of the lake respectively; Mann-Whitney $U$-test; $P=0.25$ ).

The depth distributions of the egg strands differed dramatically between the two sampling dates (Kruskal-Wallis test; $P<0.001$; Figure 4), being much shallower in late April when the peak of perch spawning activity was in the 3-4 m depth layer, compared to mid-May when the peak was in the 7-8 $\mathrm{m}$ and 11-12 $\mathrm{m}$ depth layers. On the same dates, continuous warming of the upper layers of the water column was recorded (a temperature increase of $3.2-6.5^{\circ} \mathrm{C}$ in the 3-4 m depth layer from late April to mid-May when considering individual parts of the lake; cf. Figure 3). Only during the first sampling survey were 12 egg strands found in water $<3 \mathrm{~m}$ in depth (i.e. 17.6\%; Figure 4), but even at this time no egg strands were found in water shallower than $1 \mathrm{~m}$.

The mean concentration of $D O C$ in the lake was $6.2 \mathrm{mg} \cdot \mathrm{L}^{-1}$ (min.-max., $5.7-7.6 \mathrm{mg} \cdot \mathrm{L}^{-1}$ ) indicating that according to the classification of Huff et al. (2004) Chabařovice Lake belongs to the category of higher-DOC lakes, i.e. to the category where DOC (penetrating UVR in fact) is not responsible for deep deposition of egg strands of perch.

The size (width) of the egg strands differed significantly between the two sampling dates (Kruskal-Wallis test; $P<0.001$; Figure 5) being on average $10.7 \mathrm{~cm}$ in late April and $8.7 \mathrm{~cm}$ in mid-May. In other words, larger perch females were spawning during the first compared to the second sampling survey. During each sampling date, there was no trend in the increase or decrease of the size of egg strands with the depth of deposition (regression analysis 27-30 April; $P=0.20$; regression analysis $18-20$ May; $P=0.77$; cf. Figure 5), however, when both 


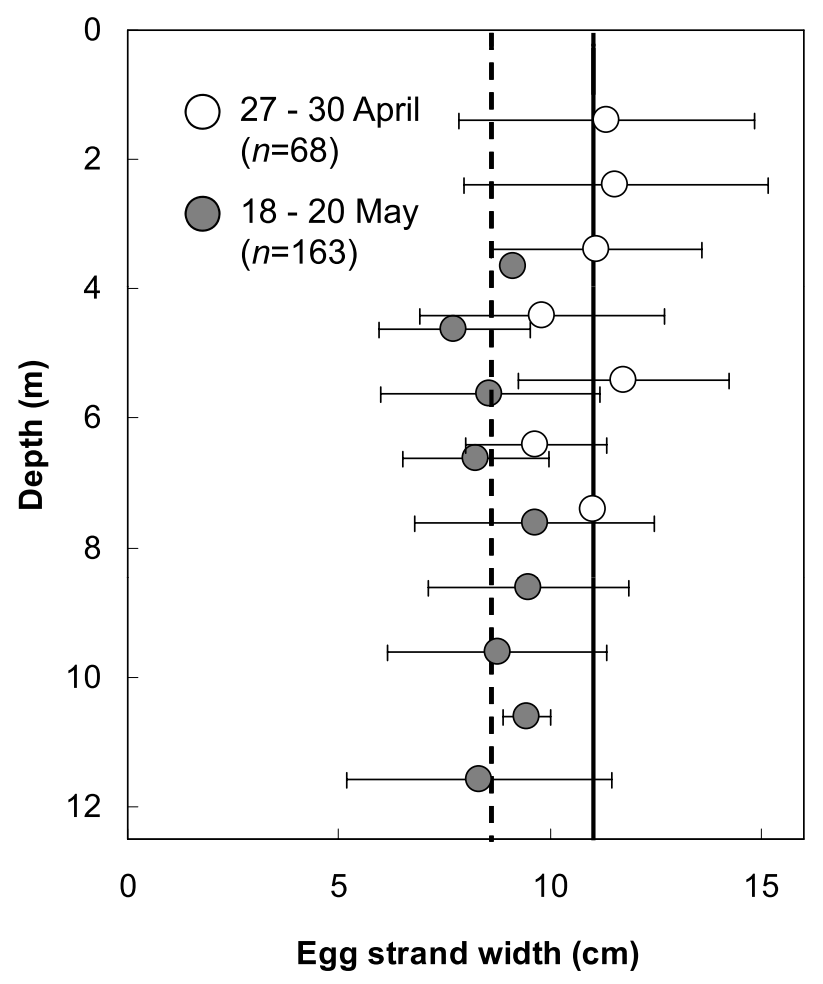

\section{Figure 5}

Sizes of egg strands (mean \pm S.D.) of perch in individual depth layers of Chabařvice Lake in spring 2009 during 27-30 April and 18-20 May. The black line shows the average width of the egg strands during the first sampling survey $(10.7 \mathrm{~cm})$, and the dashed line during the second sampling survey $(8.7 \mathrm{~cm})$.

sampling dates were combined, the size of the egg strands clearly decreased with the depth of deposition (regression analysis; $P<0.001$ ).

Although common stonewort comprised $>60 \%$ of the submerged vegetation in the $0-12 \mathrm{~m}$ depth layers of Chabařovice Lake (cf. Figure 2), the substrate most frequently used for perch spawning was common reed, worm weed and trees and branches $(82.4 \%$ of egg strands during the first survey and $80.4 \%$ of egg strands were deposited on those substrates during the second survey; Figure 6). Clearly, the perch did not use live and dead submerged vegetation in proportion to their presence in the lake $\left(\chi^{2}\right.$-test $27-30$ April; $P<0.001$ and $\chi^{2}$-test $18-20$ May; $P<0.001$ ). According to the values of the Ivlev index, perch strongly selected dead submerged vegetation (Ivlev index from 0.5 to 0.66 for dead common reed, worm weed and trees and branches; the only exception being in the case of trees and branches in late April, when these substrates were mostly too deep, i.e. still in a cold water, to be chosen for spawning) and avoided live submerged vegetation (Ivlev index from -1.00 to 0.26 for live Eurasian water milfoil, common stonewort and flooded terrestrial vegetation). Moreover, significantly larger egg strands were found to be deposited on dead submerged vegetation compared to those on live submerged vegetation (ANOVA; $P<0.01$ ). Especially in the case of common stonewort, very small egg strands were observed to be laid in between their dense stalks.

\section{DISCUSSION}

There is no doubt that wind and waves affect perch reproduction and survival in lakes. Clady and Hutchinson (1975) reported that, as a result of high winds, large quantities of eggs of yellow perch were washed ashore at a number of localities on the windward shoreline of Oneida Lake. A severe wave action caused damage to almost one percent of the estimated egg potential of the lake's perch population within a single day. Similarly, Newsome and Aalto 


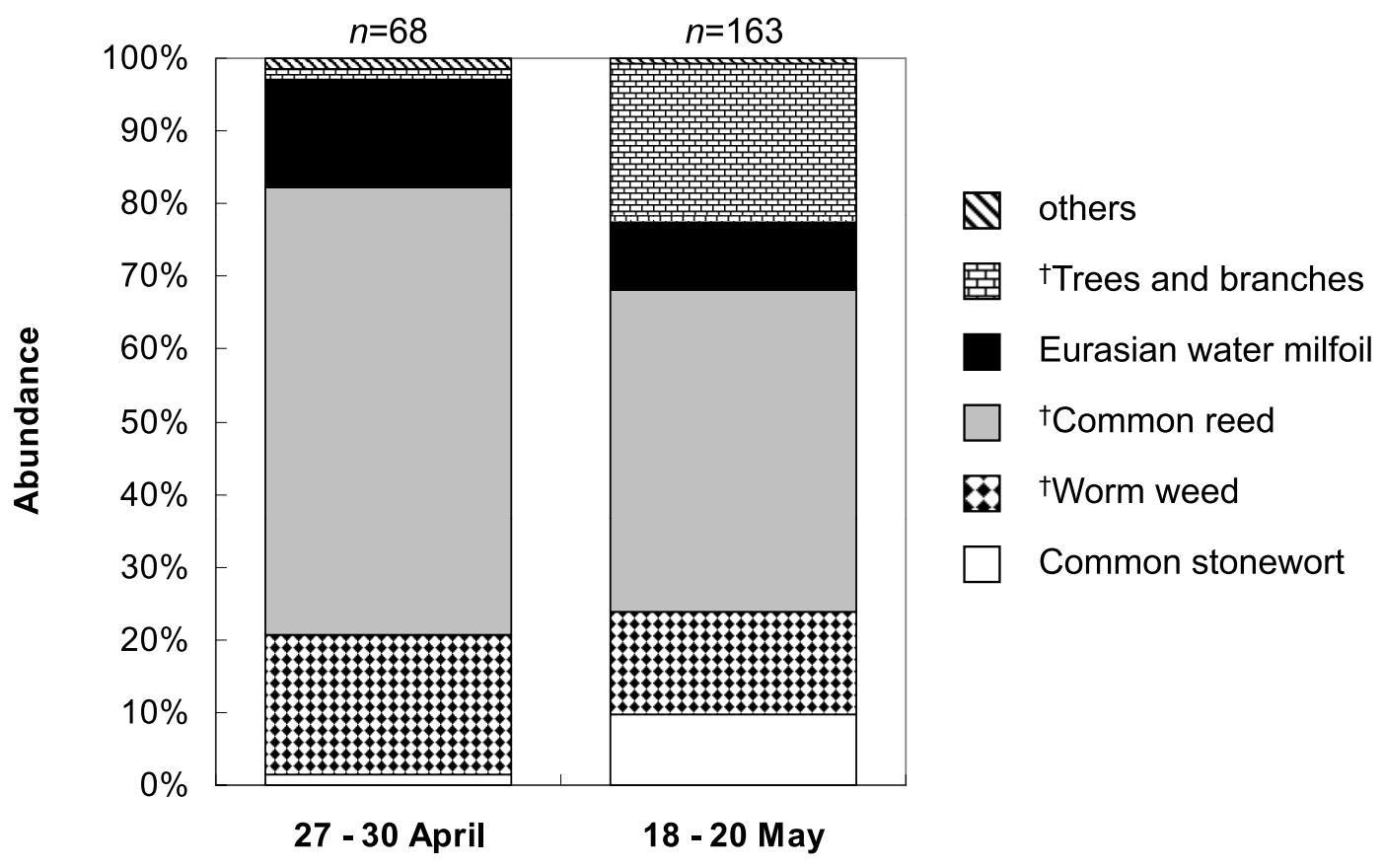

\section{Figure 6}

The composition of spawning substrate for perch in Chabařovice Lake in spring 2009 during the first days of spawning and at the end of spawning when most of the spawning events occurred in deeper parts of the lake (cf. Figure 4). † indicates dead plants, bushes or trees (for details see also Čech et al., 2009). "Others" category includes: terrestrial vegetation and fence wire-cloth.

(1987) have shown that wind-generated internal seiches in Lochaber Lake, Nova Scotia, (water temperature changed as much as $7^{\circ} \mathrm{C}$ in $15 \mathrm{~min}$ ) may result in thermal shocking of perch embryos and cause abnormal gill and jaw development, smaller body size and smaller pectoral fins. Severe deformities lead to immediate death, while intermediate deformities lead to greater susceptibility to predation.

The violent water movements might be responsible not only for mechanical damage to eggs but abrasive wave action could impose the danger of silt and other forms of deposit, which would adversely affect the development of perch eggs. These factors are of considerable importance, especially in the shallows. For that reason, in many lakes, female perch select sheltered spawning areas or deeper layers where hydrodynamic stress is of low importance (Jones, 1982; Gillet and Dubois, 1995, 2007; Probst et al., 2009).

In Chabařovice Lake, large waves generated by a long-lasting strong wind coming from the East caused drastic water mass displacement, with warm water in the west part of the lake and cold water in the east. This situation led to a significantly greater abundance of perch egg strands in the west part of the lake. It seems that female perch selectively avoided the cold, east part of the lake where the water temperature only just reached the lower limit for the usual onset of perch spawning (Kubečka, 1992; Gillet and Dubois, 2007) and they greatly preferred the warmer, west part of the lake where the water temperature was almost optimal for perch spawning (Gillet and Dubois, 1995, 2007). Moreover, nowhere in the lake were the egg strands observed in water shallower than $1.2 \mathrm{~m}$ and, in total, $91 \%$ of egg strands were deposited at depths greater than $3 \mathrm{~m}$. This finding corresponds well to the previous results from Chabařovice Lake, for 2007 and 2008 when $92 \%$ and $88 \%$ of egg strands were deposited at depths greater than $3 \mathrm{~m}$ (Čech et al., 2009, 2010). Very similar results have been published by Huff et al. (2004) from Lake Giles, Pennsylvania, where the authors have provided evidence that such a deep deposition of egg strands by yellow perch was a result of low $D O C$ concentration in the lake and thus an evolutionary response of spawning perch females to the penetrating UVR. According to the work of Williamson et al. (1997) and Huff et al. (2004), UVR has a severe damaging effect on the eggs of perch. 
In Chabařovice Lake, however, the concentration of DOC was relatively high (mean $6.2 \mathrm{mg} \cdot \mathrm{L}^{-1}$ ), suggesting that the lake belongs to the category of higher DOC lakes (for classification see Huff et al., 2004), i.e. to the category where DOC (penetrating UVR, in fact) does not evoke an avoidance reaction to shallow habitats in spawning perch and so that it is not responsible for deep deposition of egg strands. Most probably, avoidance of depths shallower than $3 \mathrm{~m}$ is a result of strong wind/waves coming from any direction, which is in accordance with previous findings of Jones (1982) from Loch Leven, Gillet and Dubois (2007) from Lake Geneva, and Probst et al. (2009) from Lake Constance. Also, in very shallow water the rapid increase of temperature during a period of calm sunny weather should not be omitted as a possible factor affecting the depth selected for deposition of egg strands. Guma'a (1978) has demonstrated that in temperatures $>14{ }^{\circ} \mathrm{C}$ a significant proportion of perch eggs die prior to hatching. In Chabařovice Lake during the period of perch spawning, the temperature in the shallow water regularly exceeds $14{ }^{\circ} \mathrm{C}$ (Čech et al., 2009, 2010), which may cause a significant risk for successful egg development.

Several studies have shown that, according to the size of egg strands, in large lakes like Lake Geneva and Lake Constance, larger perch females spawn later in the season than the small ones and that they use deeper spawning places (Gillet et al., 1995; Gillet and Dubois, 2007; Probst et al., 2009). In Chabařovice Lake, within each sampling period, there was no relationship between the size of the egg strands and the depth of deposition. However, larger females spawned significantly earlier than the smaller ones and used shallower depths (as shown by the relationship when the data from both sampling periods were pooled together). The later corresponds well with the findings of Dalimier et al. (1982) from an inundated quarry pit La Gombe, and of Holčík (1969) from Klíčava Reservoir. It seems that perch populations behave differently in small water bodies (opencast mine lake, inundated quarry pit, valley reservoir) compared to large water bodies (pre-alpine lakes).

The results of the present study have also indicated that larger perch females selected dead submerged vegetation and that, in general, this substrate was used much more for spawning (on average $81.4 \%$ of egg strands were deposited on this substrate) than was living submerged vegetation. This is particularly interesting because live submerged vegetation comprised the majority of the relevant perch spawning substrate in the lake. This finding does, however, correspond to the findings of Čech et al. $(2009,2010)$ from the same lake where, in 2007 and 2008 on average $64.7 \%$ and $91.0 \%$ of all egg strands were deposited on dead submerged vegetation. A strong preference for dead submerged vegetation could be clearly seen, especially during the second sampling period. At this time, spawning perch rather chose dead worm weed, common reed, trees and branches in the depth layer of 11-12 $\mathrm{m}$ in a temperature around $6.3^{\circ} \mathrm{C}$ (a suboptimal temperature for perch spawning and egg development; Guma'a, 1978; Gillet and Dubois, 2007) than the abundant common stonewort and Eurasian water milfoil in shallower depth layers in much more suitable temperature conditions (13.1$8.3^{\circ} \mathrm{C}$ in the $6-9 \mathrm{~m}$ depth layers; cf. Figures 2 and 4). Following the suggestion of Reyes et al. (1992), Nash et al. (1999) and Čech et al. (2009) it appears that dead submerged vegetation, such as common reed, worm weed and trees and branches, represents an ideal spawning substrate for perch because (1) it is a hard three-dimensional structure and, (2) there is much less oxygen requirement during night hours. Both factors are of crucial importance for the deposition of perch egg strands and their further development.

\section{CONCLUSION}

The present study has shown that the location and timing of perch spawning is not easy to predict even in a relatively simple system such the trough-like Chabařovice Lake, described in the recent history of this water body as without any 'obvious limitation to perch spawning' (cf. Čech et al., 2009, 2010). The important roles played by lake hydrology, temperature and the presence of appropriate spawning substrates, in particular the presence of hard threedimensional structures, have become apparent. 
Since perch is the key species in Chabařovice Lake, the progressive degradation of appropriate spawning substrates mentioned by Čech et al. $(2009,2010$; further documented in this study) is not good news for overall lake management. Due to the continuous filling of the lake the rest of the dead common reed, worm weed and trees and branches are now mostly situated in very deep water in inappropriate temperature conditions, at least at the beginning of the perch spawning period. As the presence of live submerged vegetation is less predictable in time, moreover, it is not much suitable spawning substrate for perch (Čech et al., 2009, 2010), the installation of an artificial spawning substrate (Gillet and Dubois, 1995; Dubois et al., 1996; Nash et al., 1999; Pedicillo et al., 2008; Probst et al., 2009), preferentially in depth layers of 3-8 m, would, in the near future, be an important means of both sustaining the stock of perch, the main predatory fish in the lake, and for overall management of the lake's ichthyofauna.

The results from the above mentioned attempt (artificial spawning substrate installation) on the population of perch in Chabařovice Lake would be of crucial importance for other large water bodies forming in the region of North-West Bohemia, such as the opencast mine lake Most-Ležáky (area 311 ha; filling started in 2008), Medard-Libík (area 486 ha; filling started in 2010) or Jiř́-Družba (area 1322 ha; filling will start in 2036). According to the most recent state of knowledge (Kubečka et al., pers. obs.), also in these lakes it can be expected that perch will have a key role in the initial formation of the lake's ichthyofauna, and that there will be progressive degradation of its most suitable spawning substrate in the near future.

\section{ACKNOWLEDGEMENTS}

The authors thank M. Morris for careful reading and correcting the English, and two anonymous referees for valuable comments on the manuscript. The study was supported by the Grant Agency of the Czech Republic (project No. 206/09/P266) and the Palivový kombinát Ústí, státní podnik. The Elbe River Authority kindly provided the data on DOC in May.

\section{REFERENCES}

Clady M.D. and Hutchinson B., 1975. Effect of high winds on eggs of yellow perch, Perca flavescens, in Oneida Lake, New York. T. Am. Fish. Soc., 104, 524-525.

Čech M., Peterka J., Říha M., Jůza T. and Kubečka J., 2009. Distribution of egg strands of perch (Perca fluviatilis L.) with respect to depth and spawning substrate. Hydrobiologia 630, 105-114.

Čech M., Peterka J., Říha M., Draštík V., Kratochvíl M. and Kubečka J., 2010. Deep spawning of perch (Perca fluviatilis L.) in the newly created Chabařovice Lake, Czech Republic. Hydrobiologia 649, 375-378.

Dalimier N., Philippart J.C. and Voss J., 1982. An eco-ethological study of the reproduction of Perca fluviatilis L. as observed by diving in an inundated quarry pit. Cahiers d'Éthologie Appliquée, 2/1, 37-52 (in French with summary in English).

Dubois J.P., Gillet C., Bonnet S. and Chevalier-Weber Y., 1996. Correlation between the size of mature female perch (Perca fluviatilis L.) and the width of their egg strands in Lake Geneva. Ann. Zool. Fenn., 33, 417-420.

Gillet C. and Dubois J.P., 1995. A survey of the spawning of perch (Perca fluviatilis), pike (Esox lucius), and roach (Rutilus rutilus), using artificial spawning substrate in lakes. Hydrobiologia, 300-301, 409-414.

Gillet C. and Dubois J.P., 2007. Effect of water temperature and size of females on the timing of spawning of perch Perca fluviatilis L. in Lake Geneva from 1984 to 2003. J. Fish Biol., 70, 1001-1014.

Gillet C., Dubois J.P. and Bonnet S., 1995. Influence of temperature and size of females on the timing of spawning of perch, Perca fluviatilis, in Lake Geneva from 1984 to 1993. Environ. Biol. Fish., 42, 355-363.

Guma'a S.A., 1978. The effects of temperature on the development and mortality of eggs of perch, Perca fluviatilis. Freshw. Biol., 8, 221-227. 
Holčík J., 1969. The natural history of perch, Perca fluviatilis, Linneaus 1758 , in the Klíčava reservoir. Práce Laboratoria Rybárstva, 2, 269-305.

Huff D.D., Grad G. and Williamson C.E., 2004. Environmental constraints on spawning depth of yellow perch: the roles of low temperature and high solar ultraviolet radiation. T. Am. Fish. Soc., 133, 718-726.

Ivlev V.S., 1961. Experimental ecology of the feeding of fishes, Yale University Press, New Haven, 302 p.

Jones D.H., 1982. The spawning of perch (Perca fluviatilis, L.) in Loch Leven, Kinross, Scotland. Fisheries Manag., 13, 139-151.

Kubečka J., 1992. Fluctuations in fyke-net catches during the spawning period of the Eurasian perch (Perca fluviatilis) in the Římov Reservoir, Czechoslovakia. Fish. Res., 15, 157-167.

Nash K.T., Hendry K. and Cragg-Hine D., 1999. The use of brushwood bundles as fish spawning media. Fish. Manag. Ecol., 6, 349-355.

Newsome G.E. and Aalto S.K., 1987. An egg-mass census method for tracking fluctuations in yellow perch (Perca flavescens) populations. Can. J. Fish. Aquat. Sci., 44/6, 1221-1232.

Pedicillo G., Merulli F., Carosi A., Viali P. and Lorenzoni M., 2008. The use of artificial spawning substrates as media to support the reproduction of Eurasian perch in lake Piediluco. Hydrobiologia, 609, 219223.

Peterka J., Kubečka J., Draštík V., Jůza T., Frouzová J., Čech M. and Prchalová M., 2009. Complex fish stock assessment of Chabařvice Lake in year 2008; Report of the Biology Centre, Academy of Sciences of the Czech Republic, Institute of Hydrobiology (in Czech).

Probst W.N., Stoll S., Hofmann H., Fischer P. and Eckmann R., 2009. Spawning site selection by Eurasian perch (Perca fluviatilis L.) in relation to temperature and wave exposure. Ecol. Freshwater Fish, 18, 1-7.

Rask M., Vuorinen P.J. and Vuorinen M., 1990. Delayed spawning of perch, Perca fluviatilis L., in acidified lakes. J. Fish Biol., 36, 317-325.

Reyes M.R., Arzbach H.H. and Braum E., 1992. In situ development of perch eggs, Perca fluviatilis L. (Pisces, Percidae) in a small eutrophic lake, Lake Plussee, Holstein, Germany. Int. Rev. Hydrobiol., 77, 467-481.

Sandström O., Abrahamsson I., Andersson J. and Vetemaa M., 1997. Temperature effects on spawning and egg development in Eurasian perch. J. Fish Biol., 51, 1015-1024.

Treasurer J.W., 1983. Estimates of egg and viable embryo production in a lacustrine perch, Perca fluviatilis. Environ. Biol. Fish., 8/1, 3-16.

Williamson C.E., Metzgar S.L., Lovera P.A. and Moeller R.E., 1997. Solar ultraviolet radiation and the spawning habitat of yellow perch, Perca flavescens. Ecol. Appl., 7, 1017-1023. 